\title{
Pengaruh Panjang Serat Pinang terhadap Sifat Mekanik dan Uji Biodegradabel Komposit Polipropilena Berpati Talas
}

\author{
Sonia Yong Lisha*, Alimin Mahyudin ${ }^{* *}$ \\ Laboratorium Fisika Material, Jurusan Fisika \\ Fakultas Matematika dan Ilmu Pengetahuan Alam Universitas Andalas \\ Kampus Unand Limau Manis, Padang, 25163 Indonesia \\ *soniayonglisha95@gmail.com,**aliminmahyudin23@gmail.com
}

\begin{abstract}
ABSTRAK
Telah dilakukan penelitian mengenai pengaruh panjang serat pinang terhadap sifat mekanik dan uji biodegradabel komposit polipropilena berpati talas. Variasi panjang serat $3 \mathrm{~mm}, 6 \mathrm{~mm}, 9 \mathrm{~mm}$ dan $12 \mathrm{~mm}$ dengan empat pengulangan, dengan fraksi volume serat yaitu 3\%. Sifat mekanik dan fisik yang diujikan meliputi kuat tarik, regangan, modulus elastisitas, kuat impak, dan uji biodegradabel. Penelitian ini menggunakan metode hand lay-up. Berdasarkan hasil pengujian didapatkan nilai kuat tarik tertinggi pada panjang serat $12 \mathrm{~mm}$ yaitu 19,65 MPa. Nilai regangan tertinggi ditemukan pada panjang serat $9 \mathrm{~mm}$ yaitu $4,66 \%$. Nilai kuat impak tertinggi pada panjang serat $6 \mathrm{~mm}$ dan $12 \mathrm{~mm}$ yaitu $0,0083 \mathrm{~J} / \mathrm{mm} 2$. Nilai modulus elastisitas tertinggi ditemukan pada panjang serat $6 \mathrm{~mm}$ yaitu 520,36 Mpa. Nilai uji biodegradabel rata-rata yaitu $0,0018 \%$ per hari. Pada uji spektrum FTIR sampel ukuran 5 x 1 x $1 \mathrm{~cm}$ dengan panjang serat $3 \mathrm{~mm}$ didapatkan ikatan-ikatan baru yaitu ikatan $\mathrm{N}-\mathrm{H}, \mathrm{H}-\mathrm{H}, \mathrm{C} \equiv \mathrm{C}, \mathrm{C} \equiv \mathrm{N}, \mathrm{C}=\mathrm{N}$, dan C-N.

Kata kunci: Serat pinang, pati talas, biodegradabel, kuat tarik, kuat impak, FTIR.
\end{abstract}

\section{ABSTRACT}

Research had been conducted to find the effect of areca fiber length on mechanical and biodegradation of polypropilene composites with taro strach. The variation of fiber's length are 3, 6, 9 and $12 \mathrm{~mm}$ with four times repeatation and fiber's fraction volume is 3\%. The mechanical and physical properties that had been tested including : tensile strength, strain, modulus elasticity, impact strength and biodegradation. This research used hand lay-up method. The result obtained that the highest tensile is found in $12 \mathrm{~mm}$ fiber length $19.65 \mathrm{MPa}$, the highest strain is found in $9 \mathrm{~mm}$ fiber length $4.66 \%$, the highest impact strength is found in $6 \mathrm{~mm}$ and $12 \mathrm{~mm}$ fiber's length $0.0083 \mathrm{~J} / \mathrm{mm}^{2}$, the highest modulus elasticity is found in $6 \mathrm{~mm} 520.36 \mathrm{Mpa}$, the average of biodegradation is $0.0018 \%$ per day. In FTIR spectrum in the sample $5 \times 1 \times 1 \mathrm{~cm}$ size with fiber range of $3 \mathrm{~mm}$ has been found new bounds. There are $\mathrm{N}-\mathrm{H}, \mathrm{H}-\mathrm{H}, \mathrm{C} \equiv \mathrm{C}, \mathrm{C}=\mathrm{N}$, and $\mathrm{C}-\mathrm{N}$.

Keyword: Areca nut's fiber, taro starch, biodegradation, tensile strength, impact streingth, FTIR.

\section{PENDAHULUAN}

Polipropilena merupakan salah satu contoh plastik sintetik berbahan dasar minyak bumi. Dewasa ini polipropilena sangat banyak digunakan untuk memenuhi kebutuhan manusia, salah satunya sebagai kemasan. Plastik polipropilena banyak digunakan karena memiliki sifat ringan, mudah dibentuk, tahan air dan transparan. Penggunaan plastik berbahan dasar minyak bumi membawa dampak buruk bagi lingkungan karena sulit terurai oleh mikroba di dalam tanah (Sanjaya dan Puspita, 2013). Hal ini akan menjadi masalah, oleh karena itu harus ditemukan plastik biodegradabel.

Plastik biodegradabel merupakan plastik yang pembuatannya dicampur dengan bahan yang mudah terurai, yaitu senyawa yang terkandung pada tanaman seperti selulosa dan protein. Plastik berbasis pati merupakan salah satu jenis plastik biodegradabel. Pati talas digunakan sebagai campuran matriks karena mengandung kadar amilosa sebesar 5,55\% dan kadar amilopektin sebesar $74,45 \%$.

Serat pinang merupakan salah satu bahan alam yang digunakan sebagai filler. Selain itu, juga berperan sebagai bahan yang dapat mempermudah proses degradabel. Di antara semua serat alam, pinang merupakan bahan yang menjanjikan karena murah dan ketersediaan melimpah. Penelitian tentang komposit polimer sudah dilakukan oleh beberapa peneliti, Mechtali dkk (2015) menemukan bahwa perlakuan alkali dengan $\mathrm{NaOH}$ pada komposit polipropilena dengan partikel kulit kacang almond menyebabkan modulus Young meningkat 
sebesar $14 \%$ dan nilai regangan meningkat sebesar 31\% dibandingkan dengan komposit partikel kulit almond yang tidak dilakukan perlakuan alkali.

Dynanty (2018) telah melakukan penelitian mengenai pengaruh panjang serat pinang terhadap sifat mekanik dan fisik material komposit matriks epoksi dengan penambahan pati talas. Penelitian ini dilakukan dengan variasi panjang serat yaitu $3 \mathrm{~mm}, 6 \mathrm{~mm}, 9 \mathrm{~mm}, 12 \mathrm{~mm}$, dan $15 \mathrm{~mm}$. Pada penelitian ini belum didapatkan panjang serat pinang optimum. Namun, nilai kuat tarik terbaik didapatkan pada panjang serat $3 \mathrm{~mm}$ yaitu 11,02 MPa. Nilai modulus elastisitas terbaik pada panjang serat $12 \mathrm{~mm}$ yaitu $134,52 \mathrm{MPa}$. Nilai regangan dan kuat kuat impak terbaik diperoleh pada panjang serat $9 \mathrm{~mm}$ yaitu $10 \%$ dan $0,0052 \mathrm{~J} / \mathrm{mm}^{2}$. Nilai rata-rata dari biodegradasi diperoleh sebesar 0,0098\%.

Kamagi (2017) telah menguji kekuatan mekanik dari serat buah pinang menggunakan matriks epoksi dengan fraksi volume 3\%, 5\%, 7\%, dan 9\% dengan panjang serat 3,5 cm. Hasil pengujian tarik menunjukan kekuatan tarik rata-rata terbesar terdapat pada komposit dengan presentasi volume serat $3 \%$ dengan nilai $5,614 \mathrm{~kg} / \mathrm{mm}^{2}$ atau $40,705 \mathrm{MPa}$ dan yang terkecil pada presentasi volume $7 \%$ dengan nilai $3,636 \mathrm{~kg} / \mathrm{mm}^{2}$.Nilai regangan rata-rata terbesar terdapat pada komposit dengan presentasi volume serat 3\% dengan nilai $2,48 \%$ dan yang terkecil pada presentasi volume $7 \%$ dengan nilai $2,0 \%$. Nilai modulus elastisitas rata-rata terbesar terdapat pada komposit berpenguat serat pinang 7\% dengan nilai 18,265 MPa dan terkecil pada komposit berpenguat serat pinang 9\% dengan nilai $14,548 \mathrm{MPa}$ jika dibandingkan dengan komposit berpenguat serat pinang dengan fraksi volume lainnya.

Hidayat dkk (2015) telah melakukan penelitian yang berjudul pengaruh penambahan pati talas terhadap sifat mekanik dan degradabilitas plastik campuran polipropilena dan gula jagung. Pada penelitian ini penambahan pati talas divariasikan sebanyak $0 \mathrm{~g}, 9 \mathrm{~g}, 12 \mathrm{~g}, 15 \mathrm{~g}$, dan $18 \mathrm{~g}$. Nilai kuat lentur dan tarik tertinggi diperoleh dari sampel dengan penambahan pati talas 9 g, yaitu $37,44 \mathrm{~N} / \mathrm{mm}^{2}$ dan $5,19 \mathrm{~N} / \mathrm{mm}^{2}$. Sampel yang paling cepat terdegradasi adalah sampel dengan penambahan pati talas sebanyak $18 \mathrm{~g}$, dengan laju degradasi rata-rata $0,68 \%$ per hari. Dilatarbelakangi oleh penelitian-penelitian tersebut, maka peneliti melakukan penelitian tentang pembuatan komposit polimer dengan variasi panjang serat buah pinang terhadap sifat mekanik dan uji biodegradabel komposit polipropilena berpati talas.

\section{METODE}

Penelitian dilaksanakan di Laboratorium Fisika Material Jurusan Fisika, FMIPA Unand untuk pengujian biodegradabel. Pengujian kuat tarik dan kuat impak dilakukan di Laboratorium Mekanik Politeknik Negri Padang. Teknik penelitian yang digunakan adalah metode blend dan hand lay up dengan beberapa tahapan.

\subsection{Persiapan dan Pembuatan Spesimen}

Pengolahan serat pinang dilakukan secara tradisional meliputi pemisahan dan perendaman serat. Serat direndam dengan larutan alkali $5 \% \mathrm{NaOH}$ selama 2 jam. Kemudian serat pinang dibilas dengan air untuk menghilangkan kandungan $\mathrm{NaOH}$ yang tersisa. Setelah itu serat sabut pinang dikeringkan dengan oven bersuhu $\pm 104^{\circ} \mathrm{C}$ selama 45 menit untuk meghilangkan kadar air yang tersisa. Selanjutnya serat sabut pinang dipotong sepanjang $3 \mathrm{~mm}$, $6 \mathrm{~mm}, 9 \mathrm{mmdan} 12 \mathrm{~mm}$.

Serat yang sudah diberikan perlakuan $\mathrm{NaOH}$ tersebut disiapkan $3 \%$ dari volume cetakan untuk masing-masing sampel. Resin polipropilena pelet dicairkan menggunakan hot plat dengan suhu $300^{\circ} \mathrm{C}$ selama 30 menit hingga mencair selanjutnya dicampurkan dengan pati talas sekaligus serat.

Semua bahan yang telah tercampur dituang ke dalam cetakan hingga penuh. Kemudian sampel dipadatkan dengan cara ditekan-tekan secara manual dengan spatula agar gelembung udara pada sampel berkurang. Sampel yang masih bisa dibentuk kemudian diberi pemberat dari besi padu di atas Magnetic stirrer agar semua permukaan rata. Komposit ditunggu sampai benar-benar kering dibutuhkan waktu sekitar 5 menit. Setelah komposit kering kemudian komposit dilepaskan dari cetakan. 


\subsection{Pengujian dan Pengambilan Data}

\subsubsection{Kuat Tarik}

Uji kuat tarik merupakan salah satu uji stress-strain mekanik yang bertujuan untuk mengetahui kekuatan bahan terhadap gaya tarik. Pengukuran kuat tarik dirumuskan seperti Persamaan (1):

$$
\sigma=\frac{F}{A}
$$

dengan $\sigma$ adalah kuat tarik $\left(\mathrm{kg} / \mathrm{cm}^{2}\right), F$ adalah gaya tarik tegak lurus terhadap permukaan $(\mathrm{kg})$, dan $A$ adalah luas bidang spesimen yang ditarik $\left(\mathrm{cm}^{2}\right)$.

Regangan atau strain adalah perubahan pada ukuran benda karena gaya dalam kesetimbangan dibandingkan dengan ukuran semula. Regangan dapat diukur dengan menggunakan Persamaan (2):

$$
\varepsilon=\frac{\Delta l}{l}
$$

dengan $\varepsilon$ adalah regangan, $\Delta l$ adalah perubahan panjang spesimen $(\mathrm{cm})$, dan $l$ adalah panjang spesimen $(\mathrm{cm})$.

Modulus elastisitas adalah perbandingan antara tegangan dan regangan. Modulus elastisitas didapatkan menggunakan Persamaan (3):

$$
E=\frac{\sigma}{\varepsilon}
$$

dengan $E$ adalah modulus elastisitas $\left(\mathrm{kg} / \mathrm{cm}^{2}\right)$.

\subsubsection{Kuat Impak}

Uji impak adalah jenis pengujian yang dilakukan untuk mengetahui seberapa besar kekuatan material tersebut. Nilai harga impak dapat dihitung menggunakan Persamaan (4):

$$
H I=\frac{E}{A}
$$

dengan $H I$ adalah harga impak $\left(\mathrm{J} / \mathrm{mm}^{2}\right), E$ adalah energi serap impak (J), dan $A$ adalah luas penampang $\left(\mathrm{mm}^{2}\right)$.

\subsubsection{Biodegradabel}

Metode kuantitatif yang paling sederhana untuk menguji terjadinya biodegradabel suatu polimer adalah dengan menentukan kehilangan massa dan degradabilitas material polimer. Persentase kehilangan massa dapat ditentukan dengan Persamaan (5):

$$
\% \text { massa }=\frac{m_{i}-m_{f}}{m_{i}} \times 100 \%
$$

dengan $m_{i}$ adalah massa spesimen sebelum proses biodegradabel (g) dan $m_{f}$ adalah massa spesimen sesudah proses biodegradabel $(\mathrm{g})$.

Degradabel suatu materi dapat ditentukan dengan melihat hasil persen massa yang diperoleh dalam selang waktu tertentu. Secara matematis degradabel dapat dilihat pada Persamaan (6):

\subsubsection{FTIR}

$$
\text { Degradabel }=\frac{\% \text { massa }}{\text { waktu }}
$$

FTIR (Fourier Transform Infra Red) merupakan metode analisis material dengan menggunakan spektroskopi sinar infra merah. FTIR digunakan untuk menganalisa senyawa 
organik dan anorganik serta analisa kualitatif dan analisa kuantitatif dengan melihat kekuatan absorpsi senyawa pada panjang gelombang tertentu.

\section{HASIL DAN DISKUSI}

\subsection{Kuat Tarik}

Pada penelitian ini, uji kuat tarik dilakukan untuk mengetahui seberapa besar pengaruh panjang serat terhadap kekuatan tarik, regangan, dan modulus elastisitas yang dimiliki oleh masing-masing spesimen uji. Berdasarkan Gambar 1 diperoleh nilai kuat tarik sebanding dengan panjang serat, dimana semakin panjang serat semakin besar nilai kuat tarik. Semakin besar nilai kuat tarik maka sampel yang dihasilkan akan semakin kuat terhadap beban tarik. Panjang serat 6 mm merupakan nilai kuat tarik terendah yaitu 13,7 MPa. Hal ini bisa disebabkan karena banyak void yang menyebabkan ikatan antaramuka (interface) matriks dan serat kurang baik.

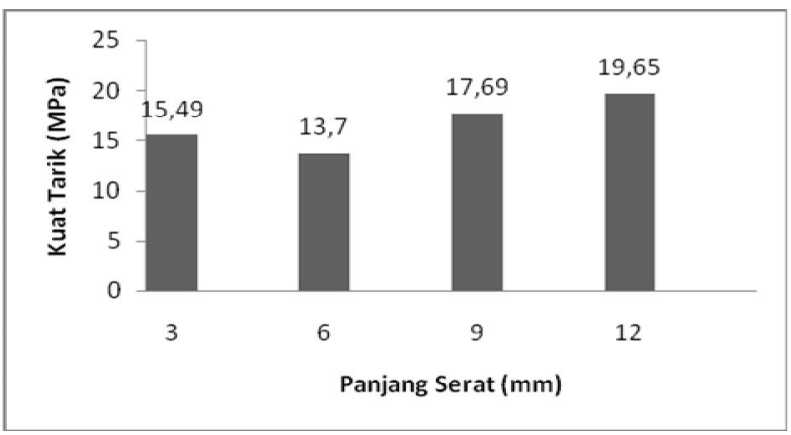

Gambar 1 Pengaruh panjang serat terhadap kuat tarik resin polipropilena dicampur pati talas

Nilai regangan dihasilkan dari perbandingan pertambahan panjang spesimen terhadap panjang mula-mula. Berdasarkan hasil dari pengujian dan perhitungan didapat data untuk nilai regangan seperti pada Gambar 2.

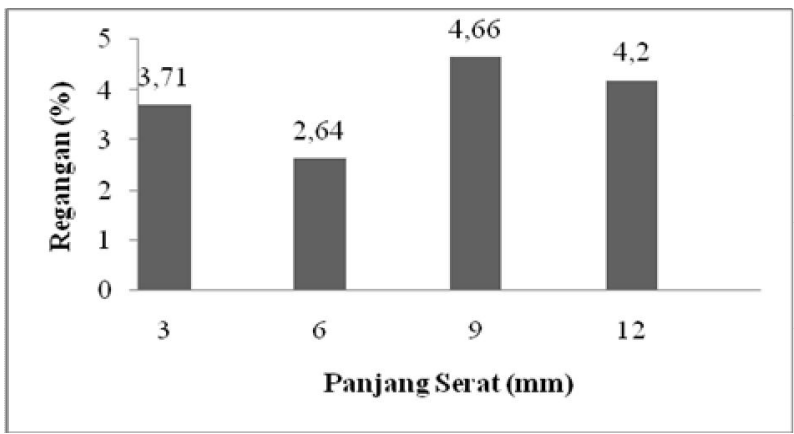

Gambar 2 Pengaruh panjang serat terhadap regangan resin polipropilena dicampur pati talas

Berdasarkan Gambar 2 nilai regangan tertinggi diperoleh pada panjang serat $9 \mathrm{~mm}$ yaitu sebesar 4,66 \% dan nilai regangan terendah diperoleh pada panjang serat $6 \mathrm{~mm}$ yaitu sebesar 2,64\%. Pada panjang serat $9 \mathrm{~mm}$ adanya gaya adhesi yang kecil yang menyebabkan ikatan antara molekulnya tidak kuat yang menyebabkan spesimen uji mudah memanjang dan terlepas dari ikatannya. Hal ini menunjukkan bahwa nilai regangan juga di pengaruhi oleh ikatan antara matriks dan serat.

Dari nilai kuat tarik dan regangan yang didapatkan, maka diperoleh nilai modulus elastisitas. Modulus elastisitas yang didapatkan dari pengaruh panjang serat pinang dapat dilihat pada Gambar 3. 


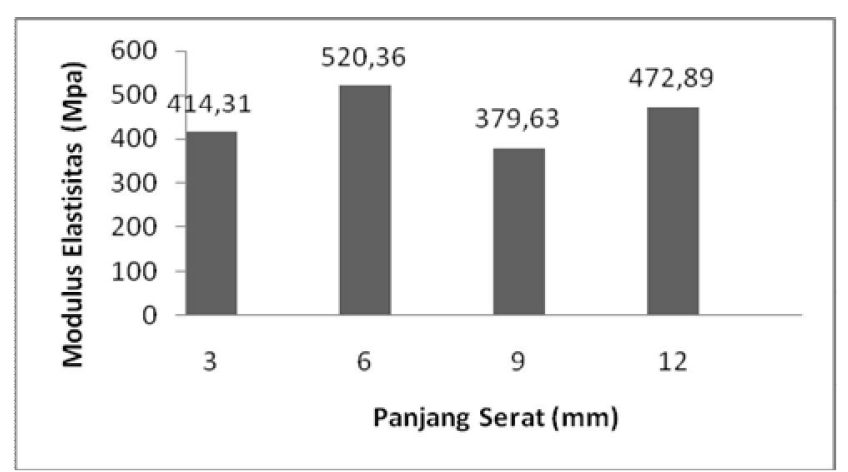

Gambar 3 Pengaruh panjang serat terhadap modulus elastisitas resin polipropilena dicampur pati talas

Gambar 3 nilai modulus elastisitas tertinggi diperoleh pada panjang serat $6 \mathrm{~mm}$ yaitu sebesar 520,36 MPa dan nilai modulus elastisitas terendah diperoleh pada panjang serat $9 \mathrm{~mm}$ yaitu sebesar 379,63 MPa. Diketahui bahwa nilai modulus elastisitas yang fluktuasi dipengaruhi oleh nilai regangan yang juga fluktuasi.

Nilai modulus elastisitas sebanding dengan kuat tarik dan berbanding terbalik dengan nilai regangan. Semakin tinggi nilai modulus elastisitas maka semakin lentur dan tidak mudah patah sampel yang dihasilkan.Terjadinya kerusakan pada sampel dikarenakan ikatan yang belum baik karena rantai antara polipropilena dengan pati talas belum terurai secara sempurna sehingga tidak tercampur merata.

\subsection{Kuat Impak}

Uji kuat impak dilakukan untuk mengetahui besarnya energi yang diserap untuk mematahkan spesimen. Berdasarkan hasil pengujian dan perhitungan didapat data seperti pada Gambar 4. Panjang serat $6 \mathrm{~mm}$ dan $12 \mathrm{~mm}$ merupakan harga impak paling tinggi yaitu 0,0083 $\mathrm{J} / \mathrm{mm} 2$. Panjang serat $9 \mathrm{~mm}$ merupakan nilai impak terendah sebesar $0,0072 \mathrm{~J} / \mathrm{mm} 2$. Hal ini dapat dikarenakan oleh campuran bahan yang masih belum kalissehingga penyerapan energi tidak terdistribusi secara merata. Semakin tinggi nilai uji kuat impak yang didapatkan maka semakin baik sampel dalam menahan beban impuls

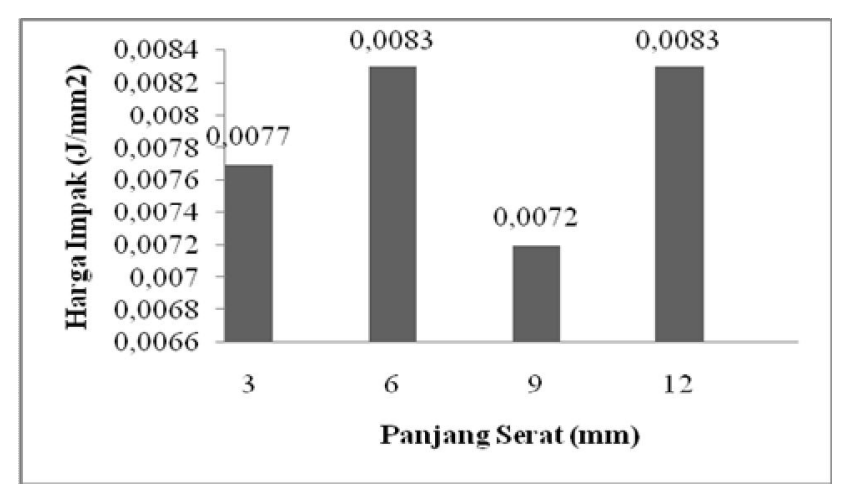

Gambar 4 Pengaruh panjang serat terhadap harga impak resin polipropilena dicampur pati talas.

\subsection{Biodegradabel}

Pengujian biodegradabel bertujuan untuk menentukan laju perubahan massa spesimen setelah penguburan. Proses degradabel dapat diketahui dengan cara melihat perubahan massa spesimen sebelum dan sesudah penguburan di dalam tanah dalam rentang waktu tertentu. Pada Gambar 5 dapat dilihat nilai degradabel spesimen setelah penguburan selama 30 hari. 


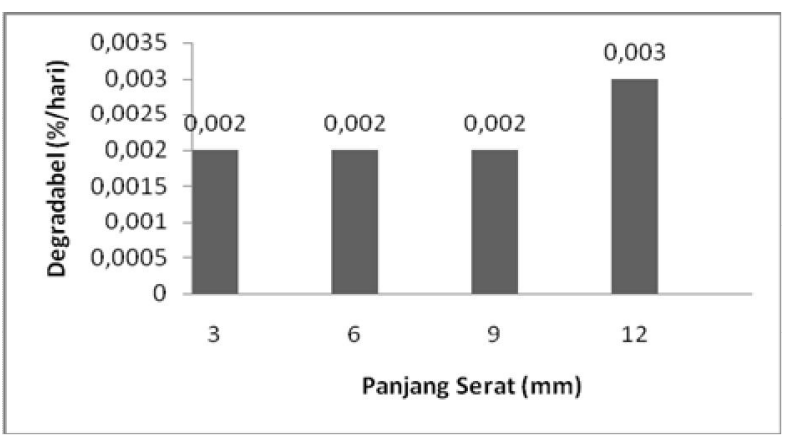

Gambar 5 Pengaruh panjang serat terhadap degradasi resin polipropilena dicampur pati talas

Panjang serat tidak terlalu signifikan mempengaruhi degradabel pada sampel karena komposisi serat pinang sama. Namun, pada sampel dengan panjang serat $12 \mathrm{~mm}$ diperoleh nilai degradabelpaling tinggi. Hal ini disebabkan oleh serat yang panjang memiliki selulosa yang banyak sehingga memudahkan mikroba untuk cepat menguraikan bahan.

\subsection{FTIR}

Ikatan polipropilena yaitu C-H pada gelombang 2951,63 $\mathrm{cm}^{-1}, \mathrm{CH}_{3}$ pada gelombang $1376,28 \mathrm{~cm}^{-1}$ dan alkena pada gelombang $997,62 \mathrm{~cm}^{-1}$ dan Ikatan pada pati talas adalah $\mathrm{C}-\mathrm{H}$, adanya gugus spektrum regangan $\mathrm{C}-\mathrm{O}$ yang berasal dari ikatan grup C-H-O.

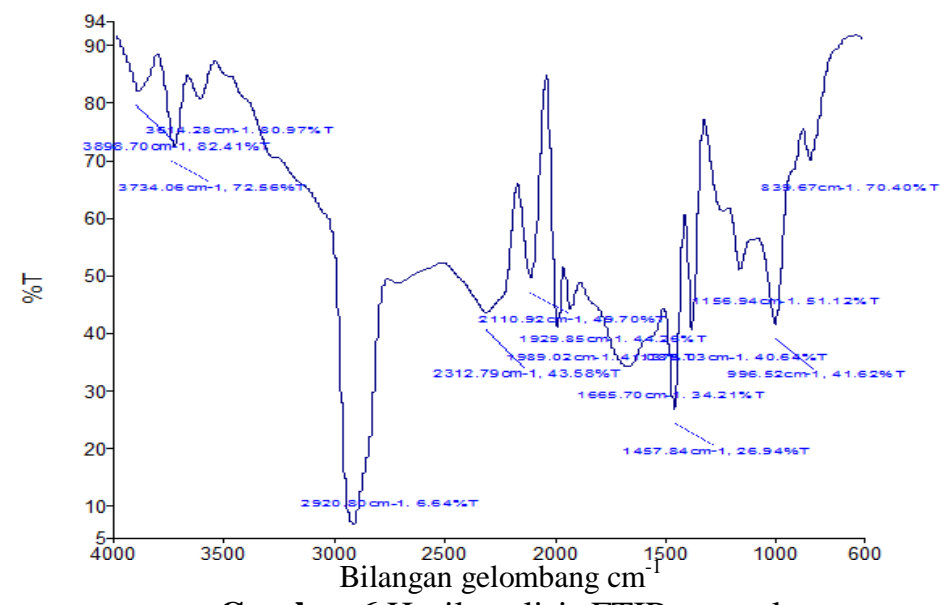

Gambar 6 Hasil analisis FTIR sampel

Berdasarkan hasil spektrum FTIR sampel didapatkan puncak-puncak bilangan gelombang yang berbeda-beda yaitu,

Tabel 1 Hasil Analisis FTIR

\begin{tabular}{|c|c|c|c|}
\hline $\begin{array}{c}\text { Bilangan } \\
\text { gelombang }\left(\mathrm{cm}^{-1}\right)\end{array}$ & $\begin{array}{c}\text { Intensitas } \\
\text { transmisi }(\%)\end{array}$ & Ikatan & Tipe senyawa \\
\hline 3898,7 & 82,41 & $\mathrm{O}-\mathrm{H}$ dan $\mathrm{N}-\mathrm{H}$ & \\
\hline 3734,06 & 72,56 & $\mathrm{O}-\mathrm{H}$ dan $\mathrm{H}-\mathrm{H}$ & \\
\hline 3614,28 & 80,97 & $\mathrm{O}-\mathrm{H}$ & $\begin{array}{l}\text { ferid, monomer alkohol, alkohol, } \\
\text { alkohol ikatan hidrogen, fenol }\end{array}$ \\
\hline 2920,8 & 6,64 & $\mathrm{C}-\mathrm{H}$ & Alkana \\
\hline 2312,79 & 43,58 & $\mathrm{C}=\mathrm{C}$ dan $\mathrm{C} \equiv \mathrm{N}$ & \\
\hline 2110,92 & 49,7 & $\mathrm{C} \equiv \mathrm{C}$ & Alkuna \\
\hline 1665,7 & 34,21 & $\mathrm{C}=\mathrm{C}$ & Alkena \\
\hline 1457,84 & 26,94 & $\mathrm{C}-\mathrm{H}$ & Alkena \\
\hline 1438,03 & 40,64 & $\mathrm{C}-\mathrm{H}$ & Alkena \\
\hline 1156,94 & 51,12 & $\mathrm{C}-\mathrm{N}$ & amina dan amida \\
\hline 996,52 & 41,62 & $\mathrm{C}-\mathrm{H}$ & Alkena \\
\hline 839,67 & 70,4 & $\mathrm{C}-\mathrm{H}$ & cincin aromatic \\
\hline
\end{tabular}


Pada penelitian ini menginformasikan bahwa terdapat ikatan-ikatan baru seperti: ikatan N-H, ikatan $\mathrm{H}-\mathrm{H}$, ikatan $\mathrm{C}=\mathrm{C}$, ikatan $\mathrm{C} \equiv \mathrm{N}$, ikatan $\mathrm{C} \equiv \mathrm{C}$, dan ikatan $\mathrm{C}-\mathrm{N}$.

\section{KESIMPULAN}

Pada penelitian ini belum diperoleh nilai panjang serat terbaik karena disetiap pengujian yang dilakukan nilai optimum terdapat pada panjang serat yang berbeda-beda. Pada hasil pengujian didapatkan nilai kuat tarik tertinggi diperoleh pada panjang serat $12 \mathrm{~mm}$ yaitu 19,65 MPa. Nilai regangan tertinggi ditemukan pada panjang serat $9 \mathrm{~mm}$ yaitu 4,66 MPa. Nilai impak tertinggi pada panjang serat $6 \mathrm{~mm}$ dan $12 \mathrm{~mm}$ yaitu $0,0083 \mathrm{~J} / \mathrm{mm} 2$. Nilai modulus elastisitas tertinggi ditemukan pada panjang serat $6 \mathrm{~mm}$ yaitu 520,36 Mpa. Nilai biodegradabel dengan penguburan sampel selama 30 hari didapatkan nilai degradabel rata-rata yaitu $0,0018 \%$. Hasil uji FTIR menginformasikan ikatan baru yaitu ikatan $\mathrm{N}-\mathrm{H}$, ikatan $\mathrm{H}-\mathrm{H}$, ikatan $\mathrm{C}=\mathrm{C}$, ikatan $\mathrm{C} \equiv \mathrm{N}$, ikatan $\mathrm{C} \equiv \mathrm{C}$, dan ikatan $\mathrm{C}-\mathrm{N}$.

\section{DAFTAR PUSTAKA}

Binoj, J.S., Raj, R.E., Sreenivasan, V.S., dan Thusnavis, G.R., "Morphological Physical, Mechanical, Chemical and Thermal Characterization of Sustainable Indian Areca Fruit Husk Fibers as Potential Alternate for Hazardous Syntethic Fibers", Journal of Bionic Engineering, 13, 156-165, 2016.

Dynanty. S. D. P., Pengaruh Panjang Serat Pinang terhadap Sifat Mekanik dan Uji Biodegradasi Material Komposit Matriks Epoksi dengan Penambahan Pati Talas, Jurnal Fisika Unand, Jurusan Fisika, Universitas Andalas, Padang, 2018.

Hidayat, R., Mulyadi, S., dan Hamdani., S., "Pengaruh Penambahan Pati Talas Terhadap sifat Mekanik dan Sifat Biodegradabel Plastik Campuran Polipropilena dan Gula Jagung", Skripsi S1, Universitas Andalas, 2015.

Kamagi, J.R.F.D., "Sifat Komposit Berpenguat Serat Buah Pinang dengan Variasi Fraksi Volume 3\%, 5\%, 7\%, dan 9\%", Skripsi S1, Universitas Sanata Dharma, 2017.

Kencanawati, C., Sugita, I.K.G., Suardana, N., dan Budiasa, I., Pengaruh Perlakukan Alkali terhadap Sifat Fisik dan Mekanik Serat Kulit Buah Pinang, Jurnal Energi dan Manufaktur, hal 6-10, 2018.

Matthews, F.L. dan Rawlings, R.D., Composite Material: Engineering And Science, (Woodhead Publishing Series in Composite Science and Engineering) (Chapman \& Hall, London, 1994).

Schwartz, M., "Composite Material Handbook", (Mc Graw Hill, New York, 1984).

Sanjaya, I.G. dan Puspita, T., Pengaruh Penambahan Khitosan Dan Plasticizer Gliserol Pada Karakteristik Plastik Biodegradable Dari Pati Limbah Kulit Singkong, Skripsi Teknik Industri, Institut Teknologi Sepuluh November, Surabaya, 2011. 